\title{
Joining technologies for a temperature-stable integration of a LTCC-based pressure sensor
}

\author{
J. Schilm ${ }^{1}$, A. Goldberg ${ }^{1}$, U. Partsch ${ }^{1}$, W. Dürfeld ${ }^{2}$, D. Arndt ${ }^{2}$, A. Pönicke ${ }^{3}$, and A. Michaelis ${ }^{1}$ \\ ${ }^{1}$ Fraunhofer IKTS, Fraunhofer Institute for Ceramic Technologies and Systems, Winterbergstraße 28, \\ 01277 Dresden, Germany \\ ${ }^{2}$ ALL IMPEX GmbH, Bergener Ring 43, 01458 Ottendorf-Okrilla, Germany \\ ${ }^{3}$ Modine Europe GmbH, Arthur-B.-Modine-Straße 1, 70794 Filderstadt, Germany \\ Correspondence to: J. Schilm (jochen.schilm@ikts.fraunhofer.de)
}

Received: 26 October 2015 - Revised: 13 January 2016 - Accepted: 26 January 2016 - Published: 9 March 2016

\begin{abstract}
Besides the well-known application as circuit boards and housings, multilayer low-temperature cofired ceramics (LTCC) offer a flexible and temperature-stable platform for the development of complex sensor elements. Commercial LTCC qualities are usually available with a matching set of metallization pastes which allow the integration of various electrical functions. However, for the integration of ceramic sensor elements based on LTCC into standardized steel housings it is necessary to compensate the mismatching thermal expansion behaviour. Therefore balancing elements made of $\operatorname{Kovar}^{\circledR}(\mathrm{Fe}-29 \mathrm{wt} \% \mathrm{Ni}-17 \mathrm{wt} \% \mathrm{Co})$ and alumina ceramic $\left(\mathrm{Al}_{2} \mathrm{O}_{3}\right)$ can be used. These components have to be joined hermetically to each other and to the LTCC sensors. In this study, brazing experiments were performed for combinations of Kovar- $\mathrm{Al}_{2} \mathrm{O}_{3}$ and Kovar-LTCC with $\mathrm{Ag}-\mathrm{Cu}-\mathrm{Ti}$ - and $\mathrm{Ag}-\mathrm{Cu}-\mathrm{In}-\mathrm{Ti}$-based commercial braze filler metals, Cusil-ABA ${ }^{\circledR}$ and Incusil ${ }^{\circledR}-\mathrm{ABA}$, respectively. For both active braze filler metals, optimized processing parameters were investigated to realize hermetic Kovar- $\mathrm{Al}_{2} \mathrm{O}_{3}$ and Kovar-LTCC joints.
\end{abstract}

\section{Introduction}

Low temperature co-fired ceramics (LTCC) is a wellknown technology for highly integrated, reliable, and hightemperature-stable microelectronic packages in mobile communication or for automotive, space, or medical applications (Peterson et al., 2008). Due to its linear stress/strain behaviour and its ability for integration of three-dimensional shapes like diaphragms, channels, and cavities, according to various authors, LTCC complies with all requirements for the integration of mechanical structures, e.g. for pressure sensors (Zarnik et al., 2010; Partsch et al., 2012; Fournier et al., 2010). A new piezo-resistive pressure sensor concept was developed by Partsch et al. (2007). Figure 1 shows a overview of a completely assembled LTCC-based pressure sensor with housing, pressure port and wiring. This new design principle allows the sensor cell to be fully mechanically decoupled and stress-free inside the sensor frame. Only thin LTCC cantilevers containing microchannels are used for the pressure connection of the sensor cell. Thick film resistors, screen- printed on the surface of the sensor cell, are connected to a Wheatstone bridge and measure the strain caused by the deflection of the LTCC diaphragm due to pressure differences in- and outside of the cell. Especially this sensor setup has been used for this study on a temperature-stable integration attempt. The LTCC technology easily enables variable sensor geometries, e.g. different diaphragm thicknesses for different pressure ranges by using different tape thicknesses and thus all types of pressure sensors (relative, absolute, differential) can be constructed. According to Fournier et al. (2010) in comparison with classic steel- or ceramicbased pressure sensors, such LTCC-based pressure sensors have many advantages like a very linear pressure-dependent signal behaviour together with an excellent high-temperature and long-term stability. Furthermore, LTCC is a high-volume technology which helps to produce sensor elements in a costeffective manner as all components of the sensor system (sensor frame, electronic components) can be integrated in one LTCC-based multilayer substrate. However, for testing, 


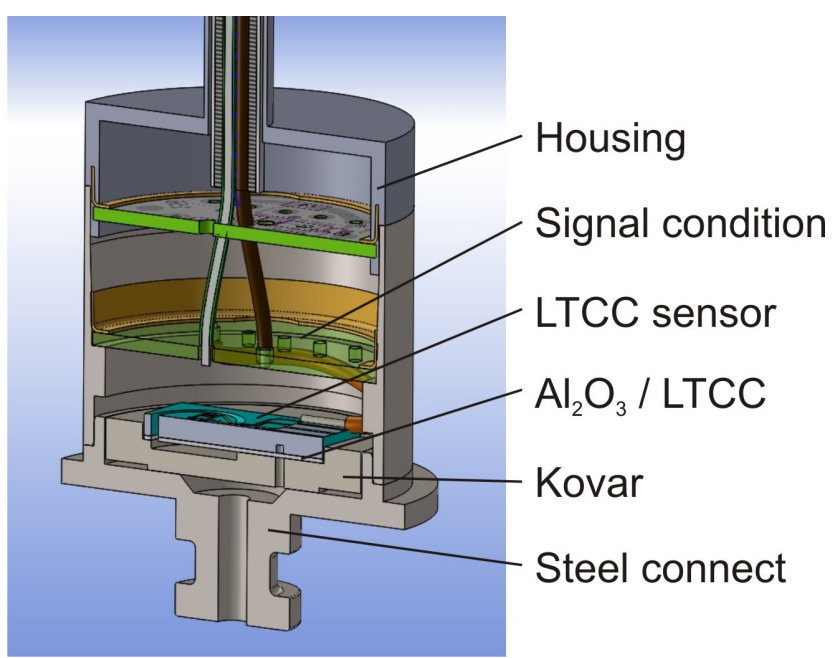

Figure 1. LTCC pressure transmitter and corresponding drawing of inner setup.

calibration, and subsequent application, the LTCC sensor elements have to be connected gas-tight to the measuring equipment. In most cases standardized steel connectors are used to ensure a gas-tight connection of the LTCC sensors to the system. But, the integration of LTCC-based sensor elements for high-temperature applications requires suitable interconnect technologies. For example, if the LTCC sensors and the steel connectors are glued directly together, the maximum operation temperature of the sensor is limited to the glass transition temperature of the epoxy resin, which is in most cases below $190^{\circ} \mathrm{C}$. Also soldering offers no reliable option as the joint strength decreases rapidly at higher temperatures due to interdiffusion processes, which in turn results in a loss of gas-tightness. For an increased thermal stability other joining technologies like glass sealing or brazing can be used. However, in this case the mismatching coefficients of thermal expansion of LTCC and steel will limit the lifetime of the integrated sensor elements as thermal cycles will initiate cracks along the sealing or inside the sensor. To overcome these problems, a stepwise integration of the LTCCbased sensor elements into steel connectors was developed. This approach offers the opportunity to outbalance the different thermal expansion coefficients of LTCC and steel, and to increase the operation range of the sensor assembly to high temperatures up to $300^{\circ} \mathrm{C}$. The integration concept is schematically shown in Fig. 2. The integration approach of LTCC-based sensors can be divided into three steps. In step A a balancing element made of a nickel-cobalt ferrous alloy, i.e. $\operatorname{Kovar}^{\circledR}(\mathrm{Fe}-29 \mathrm{wt} \% \mathrm{Ni}-17 \mathrm{wt} \% \mathrm{Co})$ with a coefficient of thermal expansion that closely matches that of the ceramic materials at low temperatures, is brazed to the steel housing. Such a steel connection produced from cost-efficient and construction steel types are necessary for having a standard interconnection interface which can be processed easily by

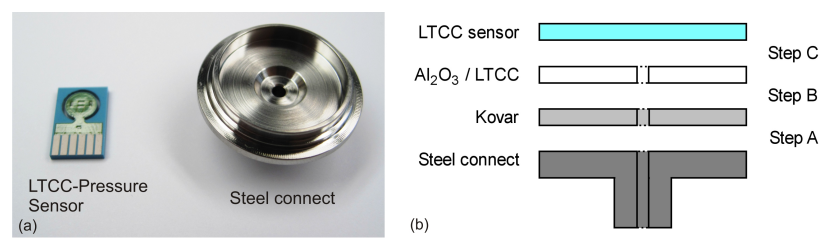

Figure 2. Single LTCC pressure and steel connect (a) and scheme for the stepwise integration of a LTCC-based sensor element into the steel connect $\mathbf{( b )}$.

electron beam welding to other devices or which may be a more complex device itself. The following step B is required in order to create a joinable surface for step $\mathrm{C}$ and will be described later in detail. In step $\mathrm{B}$ the bonding of a ceramic layer made from alumina $\left(\mathrm{Al}_{2} \mathrm{O}_{3}\right)$ or LTCC offers the possibility to integrate the LTCC-based sensor elements in step $\mathrm{C}$ by sealing with a glass-based solder or other techniques. A convenient way for the implementation of step B is the so-called active metal brazing process.

\subsection{Joining of ceramics to metals by brazing (step B)}

Fernie et al. (2009) describes several direct bonding techniques to join ceramics and metals together for hermetic joints. Besides techniques without any liquid phase like diffusion bonding or friction welding, direct bonding methods utilizing a liquid phases based on adhesives, braze filler metals, or glass solders can be used. For the desired application, where in joining step B (Fig. 2) a planar joint between Kovar and $\mathrm{Al}_{2} \mathrm{O}_{3}$ or LTCC has to be realized which is suitable for operation temperatures up to $300^{\circ} \mathrm{C}$, brazing is the appropriate method. According to Nascimento et al. (2003) a common way to braze ceramics and metals is the metallization of the ceramic prior to the brazing process since then the metallized ceramics can be brazed to metals without any active braze filler metal. However, the metallization processes imply several individual process steps, which makes them complicated and expensive. In contrast to this quite old technology Walker and Hodges (2008) describe active metal brazing as a technique which allows brazing ceramics directly to metals or themselves without any additional metallization steps. Active brazing alloys are based on filler metals like $\mathrm{Ag}, \mathrm{Ag}-\mathrm{Cu}$, or $\mathrm{Au}$ and contain low fractions of so-called active species (i.e. Ti, Zr, Hf). These elements enhance wetting of the ceramic surface during brazing in an oxygenfree environment using protective atmospheres or vacuum $\left(p<10^{-4}\right.$ mbar).

In the literature active metal brazing of Kovar to $\mathrm{Al}_{2} \mathrm{O}_{3}$ is much more extensively investigated than the brazing of Kovar to LTCC. A good overview of the problem can be found in Walker and Hodges (2013). When $\mathrm{Al}_{2} \mathrm{O}_{3}$ ceramics are brazed to themselves with $\mathrm{Ag}-\mathrm{Cu}-\mathrm{Ti}$ active braze filler metals, the joint microstructure shows a bi-layered reaction zone at the interface between the $\mathrm{Al}_{2} \mathrm{O}_{3}$ and the braz- 
ing alloy. This reaction layer consists of a Ti-rich oxide layer with a thickness below $1 \mu \mathrm{m}$ completely covering the alumina interface and a second, a few-microns-thick mixed oxide layer containing $\mathrm{Ti}, \mathrm{Cu}$, and $\mathrm{Al}$ (Stephens et al., 2003; Lin et al., 2014). $\mathrm{Al}_{2} \mathrm{O}_{3}-\mathrm{Al}_{2} \mathrm{O}_{3}$ joints prepared in this manner are hermetic and reach joint strengths of $>95 \%$ of the strength of the base material. If now one of the $\mathrm{Al}_{2} \mathrm{O}_{3}$ pieces is substituted by Kovar, the results change. Hahn et al. (1998) demonstrated in their work that Kovar- $\mathrm{Al}_{2} \mathrm{O}_{3}$ joints achieved no high strength values and reached only $40 \%$ of the initial $\mathrm{Al}_{2} \mathrm{O}_{3}-\mathrm{Al}_{2} \mathrm{O}_{3}$ joint strength. Additionally, Kovar- $\mathrm{Al}_{2} \mathrm{O}_{3}$ joints made by active metal brazing showed poor hermeticity. Stephens et al. (2000) revealed by microstructural analysis that in non-hermetic joints no continuous $\mathrm{Ti}_{x} \mathrm{O}_{y}$ reaction layers were formed at the interface between $\mathrm{Al}_{2} \mathrm{O}_{3}$ and the brazing alloy. According to Vianco et al. (2003a) this phenomenon of titanium scavenging can be explained by the dissolution of nickel and iron from Kovar in the molten braze and the strong affinity of nickel to titanium. Arróyave and Eagar (2003) describe that during the brazing process nickel and titanium react to form intermetallic compounds while the activity of titanium in the melt is decreased and the formation of the necessary reaction zone at the $\mathrm{Al}_{2} \mathrm{O}_{3}$ interface is suppressed. To improve the joint strength of $\operatorname{Kovar}-\mathrm{Al}_{2} \mathrm{O}_{3}$ and to prevent the formation of intermetallic compounds, different barrier layer concepts were developed. $\mathrm{Mo}, \mathrm{Ni}$, and $\mathrm{Mo}-\mathrm{Ni}$ coatings on Kovar were tested by Hahn et al. (1998). They report an increased bending strength of the joints by more than $80 \%$ of the uncoated base material. Vianco et al. (2003b) investigated the influence of Mo thickness and found that brazing of Kovar- $-\mathrm{Al}_{2} \mathrm{O}_{3}$ with a $500 \mu \mathrm{m}$ thick Mo barrier layer yielded the best hermeticity performance and strength. Magnetron sputtering of titanium layers on $\mathrm{Al}_{2} \mathrm{O}_{3}$ was introduced by Zhu et al. (2014) as an alternative method to improve the joint strength and gas-tightness of Kovar- $\mathrm{Al}_{2} \mathrm{O}_{3}$ joints. The mechanical metallization of alumina surfaces was applied by Nascimento et al. (2007) to achieve a proper premetallization of the ceramic component. Besides introducing barrier layers, Wielage et al. (2012) showed that an improvement of the joints is possible if induction brazing with much shorter brazing times compared to conventional furnace brazing is applied. Microstructural analysis showed a remarkable reduction of intermetallic compounds and a decrease of the reaction layer thickness between Kovar and the brazing alloy. For the desired application and workflow in step B (Fig. 2) it seems to be interesting to use LTCC as a joining partner for Kovar instead of $\mathrm{Al}_{2} \mathrm{O}_{3}$. The main reason for the use of LTCC is given by minimized thermomechanical stresses in the case of using a LTCC balancing element because it has the same coefficient of thermal expansion (CTE) value as the sensor element itself. Another reason comes from the idea that it could be possible to braze the LTCC sensor directly on the Kovar element if the required brazing temperature is low enough to avoid changes in the microstructure of the complex LTCC sensor. However, in comparison to alu- mina, less information on brazing of LTCC is available. One approach to braze LTCC is to use a metallized LTCC in combination with a non-active braze filler metal. For this purpose Keusseyan and Dilday (1993) investigated the brazeability of $\mathrm{Cu}-, \mathrm{Ag}-$, and $\mathrm{Au}$-based thick film metallization layers and concluded that for LTCC-metal joints the brazing temperature should be limited to $500{ }^{\circ} \mathrm{C}$ in order to minimize the mechanical stresses caused by the mismatching thermal expansion coefficients. Another approach, followed by Walker et al. (2006), was the investigation of PVD thin-film coatings like Ti-Au, Ti-Pt, and others. While brazing with a Ag$\mathrm{Cu}$-In braze filler metal, the Ti-Pt thin films yielded the best hermeticity performance and highest strength. However, on active metal brazing of LTCC without further metallization layers only one study was found in the literature. Furthermore Walker et al. (2006) stated that hermetic joints of LTCC and Kovar were only be possible if the LTCC was ground and re-fired prior to the brazing process. As shown, brazing of LTCC only is less investigated, and no systematic results are given in the literature which let one judge about the suitability of the active metal brazing technique for LTCC. In the case of $\mathrm{Al}_{2} \mathrm{O}_{3}$, besides $\mathrm{Ag}-\mathrm{Cu}-\mathrm{Ti}$ active braze filler metals, no brazing alloys with lower brazing temperatures were tested. Thus in the present study the commercially available active braze filler metal Incusil ${ }^{\circledR}$-ABA is investigated to provide brazing parameters as a means to obtain hermetically brazed Kovar- $\mathrm{Al}_{2} \mathrm{O}_{3}$ and Kovar-LTCC joints. For comparison with the literature, joining of $\mathrm{Al}_{2} \mathrm{O}_{3}$ and LTCC to Kovar with Cusil-ABA ${ }^{\circledR}$ was investigated as well.

\section{Methods and materials}

\subsection{Ceramic materials}

The LTCC sensors are based on DuPont's GreenTape 951 system, as this material system is a fair compromise in comparison to other ceramic co-firing materials regarding Young's modulus and fracture strength. While the exact composition of this LTCC quality is not published by DuPont, within this work it is important to know that the main crystalline phase consists of $\mathrm{Al}_{2} \mathrm{O}_{3}$ grains which are bonded by a PbO-based glass frit. For joining experiments LTCC samples were made by laminating three tape layers followed by a firing process with a peak temperature of $850^{\circ} \mathrm{C}$ similar to the one described by Fournier et al. (2010). After firing the sintered LTCC had a thickness of $630 \mu \mathrm{m}$ and was cut into single samples $\left(7 \times 7 \mathrm{~mm}^{2}\right)$ with a dicing saw. The surface roughness of the as-fired LTCC was Ra $<0.36 \mu \mathrm{m}$. The alumina ceramic was obtained in thick film standard quality with an $\mathrm{Al}_{2} \mathrm{O}_{3}$ content of $96 \%$ (Rubalit $^{\circledR} 708 \mathrm{~S}$, CeramTec, Marktredwitz, Germany), a thickness of $250 \mu \mathrm{m}$, and a surface roughness of $\mathrm{Ra}<0.36 \mu \mathrm{m}$. Samples were prepared by laser scribing and subsequent breaking along the scribed lines. As metallic joining partners, balancing elements made of Kovar were prepared from a massive rod according to the 
Table 1. Active metal brazing filler metals with their compositions and brazing temperatures.

\begin{tabular}{lrrrrr}
\hline Brazing filler metal & $\mathrm{Ag}(\mathrm{wt} \%)$ & $\mathrm{Cu}(\mathrm{wt} \%)$ & $\mathrm{In}(\mathrm{wt} \%)$ & $\mathrm{Ti}(\mathrm{wt} \%)$ & Brazing temperature \\
\hline Incusil-25-ABA & 43.6 & 29.1 & 24.3 & 3.0 & $650^{\circ} \mathrm{C}$ \\
Incusil-ABA & 59.0 & 27.25 & 12.5 & 1.25 & $755^{\circ} \mathrm{C}$ \\
Cusil-ABA & 63.0 & 35.25 & & 1.75 & $810-850^{\circ} \mathrm{C}$ \\
\hline
\end{tabular}

sensor setup indicated in Fig. 1. The bottom side of the element will be brazed to the steel interconnect and the cavity in the upper side a ceramic balancing substrate made of $\mathrm{Al}_{2} \mathrm{O}_{3}$ or LTCC will be brazed by an active metal brazing process. The Kovar components additionally contain a channel structure that allows access of the pressurized gas to the sensor membrane. The surfaces of all samples were degreased prior to assembly and brazing processes.

\subsection{Brazing and glass sealing}

In accordance with the previously described integration strategy, two brazing processes - one for joining the steel connect to Kovar and one for joining Kovar to $\mathrm{Al}_{2} \mathrm{O}_{3}$ - have been selected. A one-step brazing process appears to be more favourable but offers fewer opportunities for a process control regarding the hermeticity of the different interfaces. For this reason the brazing processes were separated. For the first brazing joint between steel and Kovar, a nickel-based brazing foil (MBF-20 from Metglas Inc., Conway, SC, USA) is applied which has a liquidus temperature well above the active filler metal brazes used for the second brazing process. For this purpose the MBF-20 brazing foil was cut by a laser process into shapes matching strictly to the joined side of the components. The foils were placed in between both components adjusted with an additional load on top of the arrangement and brazed in vacuum $\left(<1 \times 10^{-5} \mathrm{mbar}\right)$ with the following brazing cycle: from room temperature at $5 \mathrm{~K} \mathrm{~min}^{-1}$ to $940^{\circ} \mathrm{C}$ with a hold for $15 \mathrm{~min}$ in order to achieve a homogenous furnace temperature and than again with $5 \mathrm{~K} \mathrm{~min}^{-1}$ up to the brazing peak temperature of $1055^{\circ} \mathrm{C}$ with an additional hold time of $15 \mathrm{~min}$. Cooling down to room temperature was conducted at $3 \mathrm{~K} \mathrm{~min}^{-1}$.

For joining of the ceramics $\left(\mathrm{Al}_{2} \mathrm{O}_{3}\right.$ and LTCC) to Kovar, three types of braze filler metals provided by Wesgo Metals (Hayward, CA, USA) were used, which are listed in Table 1. These alloys were applied in the form of laser cut foils with a thickness of $50 \mu \mathrm{m}$. Brazing was carried out in a full-metal vacuum furnace with molybdenum heating elements at a pressure $<1 \times 10^{-5}$ mbar. The following process cycle was used for brazing: heating from room temperature to $550^{\circ} \mathrm{C}$ (for Incusil-ABA) or $700^{\circ} \mathrm{C}$ (Cusil-ABA) at a rate of $10 \mathrm{~K} \mathrm{~min}^{-1}$, holding for $20 \mathrm{~min}$ to obtain a temperature homogenization inside the furnace, further heating up to the desired brazing temperature (Table 1), holding of brazing temperature for $10 \mathrm{~min}$, and then cooling down to room

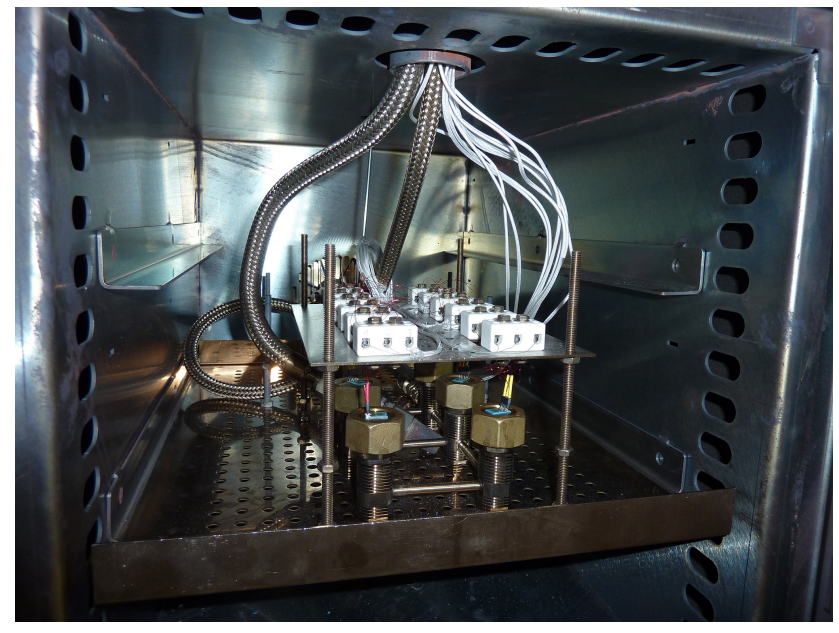

Figure 3. High temperature pressure measurement station for characterizing sensors up to $200 \mathrm{bar}$ and $650{ }^{\circ} \mathrm{C}$.

temperature at a rate of $5 \mathrm{~K} \mathrm{~min}^{-1}$ to $400{ }^{\circ} \mathrm{C}$ with subsequent furnace cooling. The brazing temperatures were varied between 810 and $850^{\circ} \mathrm{C}$ for Cusil-ABA in order to investigate the influence of brazing temperature on gas-tightness and microstructure of the joined assemblies. For the final integration of the LTTC sensor into this prepared steel connector, a commercially available, lead-free sealing glass from ASAHI (4115DS-NY01) supplied as a ready-to-use paste with an appropriate firing profile having a peak temperature of $500^{\circ} \mathrm{C}$ for use in muffle furnace was screen-printed on the back side of the LTCC sensor element. For the joining process the sensor was placed on the ceramic balancing element together with a mechanical load of $10 \mathrm{~g}$.

\subsection{Characterization}

Upon brazing, the gas-tightness of each brazed assembly in each integration step was measured using a helium leak detector (Phoenix XL30, Oerlikon Leybold Vacuum, Cologne, Germany). A joint with a helium leak rate of $1 \times 10^{-8} \mathrm{mbar} \mathrm{s}^{-1}$ or better was considered as hermetic. Microstructural analysis of the joints was performed on polished cross-sectioned samples using a scanning electron microscope (abbreviation: SEM; NVision 40, Carl Zeiss SMT, Oberkochen, Germany). The micrographs shown in this paper were recorded in the element specific back-scattered electron mode. Additionally, the scanning electron microscope 

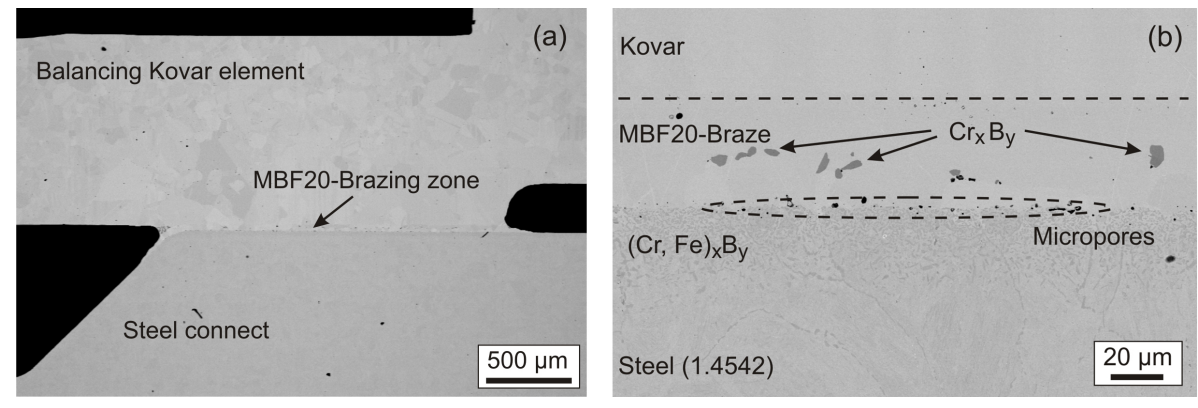

Figure 4. Scanning electron micrographs of steel (1.4542)-Kovar joints brazed with MBF-20 showing an overview in (a) and details of the microstructure in (b).

is equipped with an energy dispersive X-ray analysis system (abbreviation: EDX; Inca X-sight, Oxford Instruments, Abingdon, England), which allows for a quantitative detection of elements.

The characteristic of the pressure sensor is performed by a newly developed pressure measurement system. The sensors can be measured in a special chamber oven KU70/07-A of the company THERMCONCEPT using a high-temperaturecapable pressure rail and a ceramic-insulated electrical wiring for a temperature range of $25-650^{\circ} \mathrm{C}$. At the same time, the sensors were applied by means of pressure controller PACE 5000 of the company GE Measurement \& Control in the range of $0-200$ bar with and the characteristic curve is measured with a computer-controlled system. Figure 3 shows the inner setup of this newly developed measurement device which allows the simultaneous characterization of 6 sensors at maximum in the range of $25-600^{\circ} \mathrm{C}$.

\section{Results and discussion}

As claimed in the Introduction and with respect to the chosen integration strategy, especially the joining process of metals to ceramics represent a challenge. Active metal brazing of Kovar and similar alloys to $\mathrm{Al}_{2} \mathrm{O}_{3}$ by active metal brazes is not generally a new topic, but in terms of reduced brazing processing temperatures the use of indium-containing active metal brazes appears attractive. In the case of the $\mathrm{SiO}_{2}$ - and $\mathrm{PbO}$-containing LTCC material it can be supposed that the active component titanium in the active metal brazing alloy will undergo a redox reaction with these oxides. Possible reaction products could be titanium silicides of titanium-lead intermetallic compounds. Especially the formation of silicides with different components of high-temperature-stable brazing alloys is described by McDermid and Drew (1991) or Liu et al. (2009). Such intermetallic phases have a brittle character and can have disadvantageous effects on the adhesion of the braze at the ceramic surfaces. For these reasons special interest must be paid to the interfacial reactions between the different brazing alloys and joint materials in order to identify proper brazing alloys and brazing conditions.

\subsection{Brazing of Kovar and steel}

Brazing of the balancing Kovar element into the steel housing is the first step of the integration procedure. In accordance with brazing temperatures which are required for active filler braze between 750 and $850^{\circ} \mathrm{C}$, it is necessary to perform this brazing step at a higher temperature which lies well above the formerly mentioned one. One must take care on stability of the Kovar alloy and potential reactions with the filler braze. Based on these boundary conditions MBF-20, an amorphous nickel braze filler metal was chosen. The brazing process, was performed at temperatures between 1040 and $1060^{\circ} \mathrm{C}$. The micrograph in Fig. 4a shows an overview of the brazing zone indicating a good and pore-free adhesion of both components. A closer look at Fig. 4b reveals the formation of darker chromium borides which are brittle intermetallic phases in the brazing alloy. This indicates that chromium from the steel slightly dissolves into the molten brazing alloy MBF-20, which also contains small amounts of boride for reduced melting temperatures. Without going into much into detail we can say that it was possible to achieve hermetic dense joints with this materials and the SEM investigations gave no hints for significant interfacial reactions. With these results the CTE adjusted steel connector for the further integration of the ceramic components is available.

\subsection{Brazing KOVAR to ceramic interlayer}

\subsubsection{Brazing with Incusil-ABA}

Active metal brazing of LTCC and $\mathrm{Al}_{2} \mathrm{O}_{3}$ to Kovar with Incusil-ABA at $755^{\circ} \mathrm{C}$ for 10 min yields in both cases to hermetically sealed assemblies. Surprisingly, we were able to realize hermetic joints of as-fired LTCC and Kovar, which is in sharp contrast to the results of Walker et al. (2006). SEM images of the microstructures of Kovar- $-\mathrm{Al}_{2} \mathrm{O}_{3}$ and Kovar-LTCC joints brazed with Incusil-ABA are shown in Fig. 5a and $\mathrm{b}$, respectively. These micrographs show the typical structure of the $\mathrm{Ag}-\mathrm{Cu}-\mathrm{In}$ eutectic with a $\mathrm{Ag}$-rich phase (white regions, with dissolved $\mathrm{In}$ and $\mathrm{Cu}$ ) and a $\mathrm{Cu}-$ rich phase (grey regions) together with enclosed intermetallic phases in the brazing alloy (dark grey regions) and reac- 

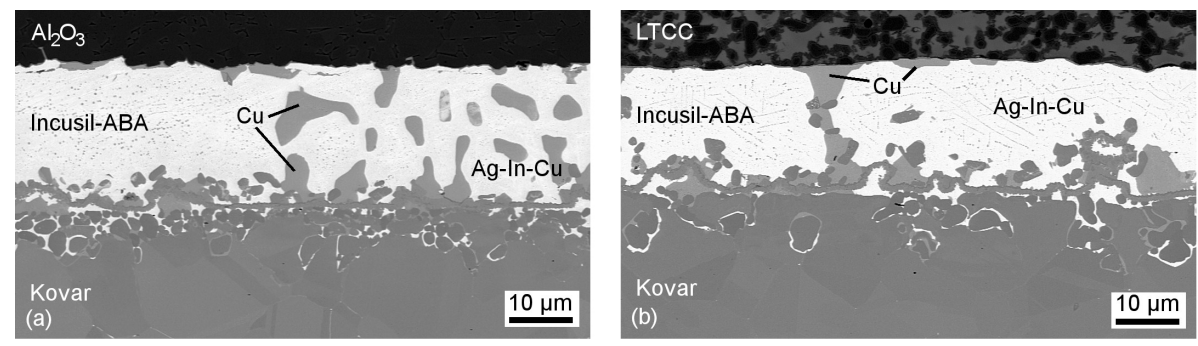

Figure 5. SEM images of Kovar- $\mathrm{Al}_{2} \mathrm{O}_{3}$ (a) and Kovar-LTCC (b) joints brazed with Incusil-ABA at $755^{\circ} \mathrm{C}$ for $10 \mathrm{~min}$.
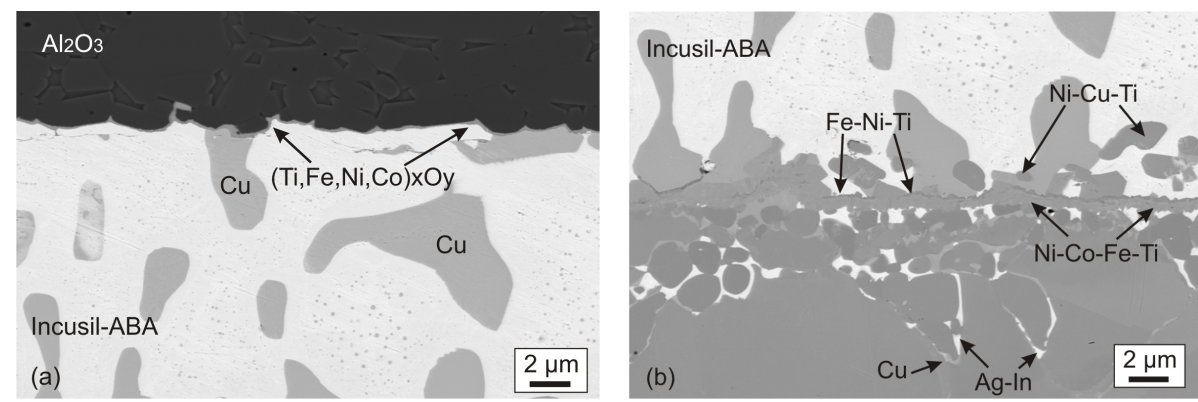

Figure 6. Enlarged SEM images of Fig. 5a showing the $\mathrm{Al}_{2} \mathrm{O}_{3}$ /Incusil-ABA (a) and the Kovar/Incusil-12.5-ABA interfaces (b).
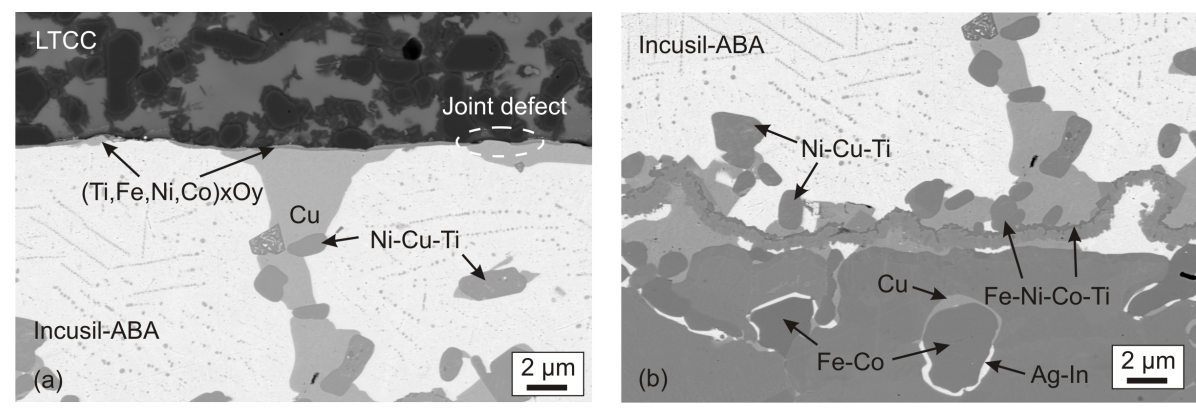

Figure 7. Enlarged SEM images of Fig. 5b showing the LTCC/Incusil-ABA (a) and the Kovar/Incusil-12.5-ABA interfaces (b).

tion layers on both interfaces. Figure $6 \mathrm{a}$ and $\mathrm{b}$ are the enlarged images from Fig. 5a displaying the reaction layers at the interface between $\mathrm{Al}_{2} \mathrm{O}_{3}$ and the brazing alloy, and between Kovar and the brazing alloy, respectively. At the interface between $\mathrm{Al}_{2} \mathrm{O}_{3}$ and the brazing alloy a very thin reaction layer with submicron thickness was formed. This reaction layer completely covers the alumina interface, yielding a mean helium lake rate of $6 \times 10^{-10} \mathrm{mbar} \mathrm{s}^{-1}$. The main constituents of the reaction layer are $\mathrm{Ti}$ and $\mathrm{O}$, but also elements of the Kovar, i.e., $\mathrm{Ni}, \mathrm{Fe}$, and $\mathrm{Co}$, are detected. This suggests that the constituents of the $\mathrm{Fe}-\mathrm{Ni}-\mathrm{Co}$ alloy show a strong affinity to Ti even at lower temperatures than in the publications of Stephens et al. (2000) and Vianco et al. (2003a). The strong reactivity of $\mathrm{Fe}, \mathrm{Ni}$, and $\mathrm{Co}$ with $\mathrm{Ti}$ shaped the interface between Kovar and the brazing alloy as several intermetallic compounds like $(\mathrm{Fe}, \mathrm{Ni}, \mathrm{Co})_{x} \mathrm{Ti}_{y}$ with a high amount of $\mathrm{Ni}$ (abbreviation: $\mathrm{Ni}-\mathrm{Co}-\mathrm{Fe}-\mathrm{Ti}$ ) or Fe (abbreviation: $\mathrm{Fe}-$ $\mathrm{Ni}-\mathrm{Co}-\mathrm{Ti}$ ) are observed. These intermetallic phases form a small band which meanders parallel to the Kovar surface. Further away from the interface in the brazing alloy $\mathrm{Ni}-\mathrm{Cu}-$ Ti compounds are visible. In addition, down to a depth of $25 \mu \mathrm{m}, \mathrm{Ag}, \mathrm{In}$, and $\mathrm{Cu}$ from the brazing alloy are found at the grain boundaries of the Kovar and along $\mathrm{Fe}-\mathrm{Co}$ grains which are depleted of $\mathrm{Ni}$. In comparison with $\mathrm{Kovar}-\mathrm{Al}_{2} \mathrm{O}_{3}$ joints, the microstructure of Kovar-LTCC joints with IncusilABA looks similar. Figure $7 \mathrm{a}$ and $\mathrm{b}$ are the enlarged images from Fig. 5b showing the interfaces between LTCC and the brazing alloy, and between Kovar and the brazing alloy, respectively. Again, through diffusion of $\mathrm{Fe}, \mathrm{Ni}$, and $\mathrm{Co}$ and their reaction with the active element $\mathrm{Ti}$, intermetallic compounds were formed in the brazing alloy and along the interface to Kovar. However, in the micrographs two differences in comparison with Kovar- $\mathrm{Al}_{2} \mathrm{O}_{3}$ joints are found. Firstly, the very thin $(\mathrm{Ti}, \mathrm{Fe}, \mathrm{Ni}, \mathrm{Co})_{x} \mathrm{O}_{y}$ reaction layer at the interface LTCC/brazing alloy contains traces of $\mathrm{Si}$ and $\mathrm{Pb}$, the main constituents of the glass phase of the LTCC. Secondly, 

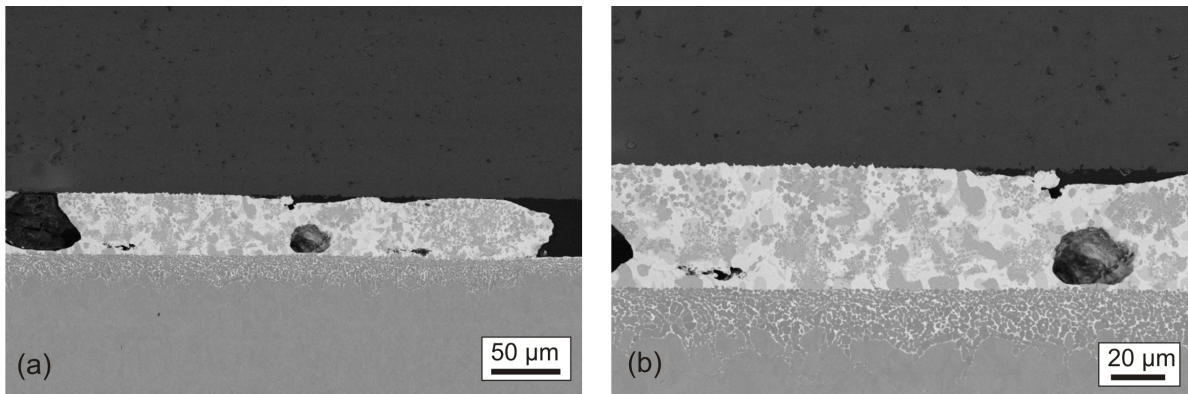

Figure 8. SEM images of Kovar- $\mathrm{Al}_{2} \mathrm{O}_{3}$ joints brazed with Incusil-25-ABA at $650^{\circ} \mathrm{C}$ for $10 \mathrm{~min}$.

Table 2. Hermeticity after brazing with Cusil-ABA as a function of brazing parameters.

\begin{tabular}{lrr}
\hline Joint setup & $\begin{array}{r}\text { Peak process } \\
\text { temperature }\end{array}$ & $\begin{array}{r}\text { Hermetic joints } \\
\text { (fraction) }\end{array}$ \\
\hline $\mathrm{Al}_{2} \mathrm{O}_{3}$-Kovar & $810^{\circ} \mathrm{C}$ & $2 / 6$ \\
$\mathrm{Al}_{2} \mathrm{O}_{3}-$ Kovar & $830^{\circ} \mathrm{C}$ & $12 / 12$ \\
$\mathrm{Al}_{2} \mathrm{O}_{3}-$ Kovar & $850^{\circ} \mathrm{C}$ & $6 / 6$ \\
$\mathrm{LTCC}-$ Kovar & $810^{\circ} \mathrm{C}$ & $2 / 6$ \\
LTCC-Kovar & $830^{\circ} \mathrm{C}$ & $6 / 6$ \\
LTCC-Kovar & $850^{\circ} \mathrm{C}$ & Not tested \\
\hline
\end{tabular}

the reaction layer is non-continuous with some pores where the brazing alloy was not able to wet the LTCC completely. However, all brazed assemblies were hermetic with an average helium lake rate of $4 \times 10^{-9} \mathrm{mbar} \mathrm{s}^{-1}$.

Further experiments were conducted by using the Incusil25-ABA brazing paste. An apparent advantage of the brazing alloy is the lower processing temperature between 640 and $680^{\circ} \mathrm{C}$. Within the scope of this study it was not possible to achieve hermetically brazed joints between $\mathrm{Al}_{2} \mathrm{O}_{3}-$ Kovar and LTCC-Kovar while using the Incusil-25-ABA brazing alloy. The wetting of the braze on the Kovar surface was excellent, which in turn led to spreading of the melt out of the brazing gap all over the Kovar surface. As a consequence the brazing joints contained numerous and quite large pores, and a porous microstructure was formed as seen in Fig. 8a. Also the reason for the excellent wetting can be taken form the SEM images in Fig. 8. A strong interaction between the active metal braze and the Kovar alloy leads to the destruction of the microstructure beneath the Kovar surface and is quite more pronounced than is the case for the Incusil-ABA braze. This strong reactivity enables the wetting of the molten brazing alloy on the Kovar. Also here the dissolution of the Kovar into the brazing melt results in the formation of nickeltitanium-based phases in the brazing alloy, which can be recognized as the darker disperse phase in the brazing zone. In accordance with the enhanced dissolution of the Kovar, this phase formation seems to be more pronounced. However Incusil-25-ABA contains more titanium than Incusil-ABA,

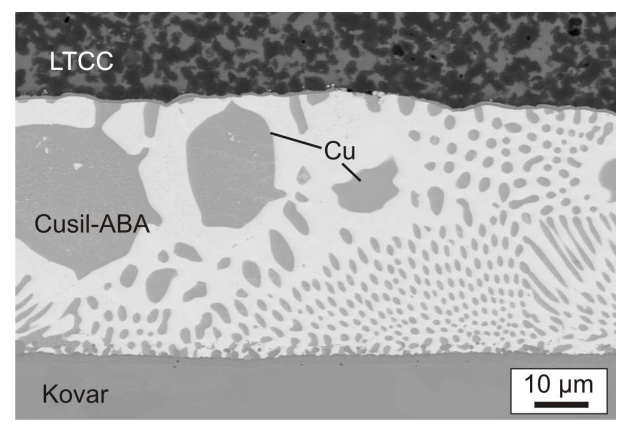

Figure 9. SEM image of a Kovar-LTCC joint brazed with Cusil$\mathrm{ABA}$ at $810^{\circ} \mathrm{C}$ for $10 \mathrm{~min}$.

which may also be a reason for the stronger phase formation. This reaction captures at least a fraction of the activephase titanium from the brazing alloy which is necessary to enable a wetting process on ceramic surfaces. Thus due to insufficient brazing results no further experiments were performed with this brazing alloy containing a high percentage of indium. The presented results showed that brazing of Kovar with indium-containing active braze filler metals leads to considerable destruction of the Kovar microstructure. An optimization of the brazing cycle could help to minimize this behaviour. However this was beyond the scope of the present study and will be addressed in the future. As explained in the next section, the indium-free Cusil-ABA braze filler metal leaves the microstructure of the Kovar nearly intact.

\subsubsection{Brazing with Cusil-ABA}

Active metal brazing of $\mathrm{Al}_{2} \mathrm{O}_{3}$ and LTCC to Kovar with Cusil-ABA was performed at three different brazing temperatures for a minimum of six samples for each brazing condition. Table 2 summarizes the obtained hermeticity data. While brazing of $\mathrm{Al}_{2} \mathrm{O}_{3}$ yielded to hermetically sealed assemblies in most cases, brazing of LTCC gave rather different results. After brazing of LTCC-Kovar joints at a temperature of $810^{\circ} \mathrm{C}$, only a few of the assemblies were hermetic (Fig. 9). Microstructural investigation showed that the interface between LTCC and the brazing alloy is weakly bonded 

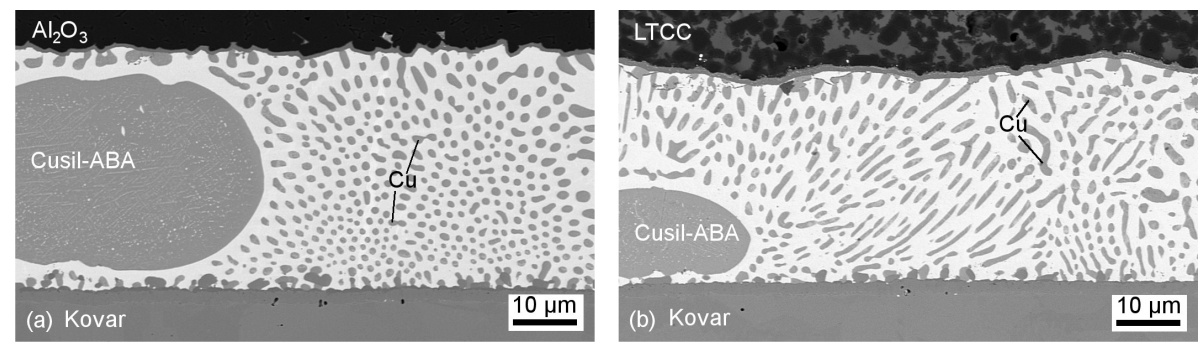

Figure 10. SEM images of Kovar- $\mathrm{Al}_{2} \mathrm{O}_{3}$ (a) and Kovar-LTCC (b) joints brazed with Cusil-ABA at $830{ }^{\circ} \mathrm{C}$ for $10 \mathrm{~min}$.
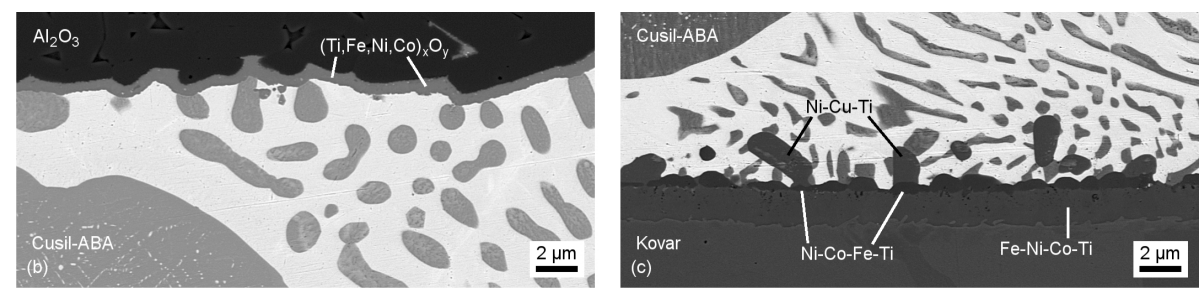

Figure 11. Enlarged SEM images of Fig. 10a showing the $\mathrm{Al}_{2} \mathrm{O}_{3}-\mathrm{Cusil-ABA}$ (a) and the Kovar-Cusil-ABA interfaces (b).

because it seems that only a non-continuous and thin reaction layer was formed. Thus at this brazing temperature no reliable joining was possible. When the brazing temperature was increased to $830^{\circ} \mathrm{C}$, all brazed LTCC-Kovar joints showed gas-tightness due to the formation of a continuous reaction layer at the interface between LTCC and Kovar, which is shown later in detail. Due to the fact that this brazing temperature is close to the sintering temperature of the LTCC tape, it was initially assumed that brazing is not possible because of softening of the residual glassy phase in the LTCC. This was not confirmed, and the results showed strong and hermetic bonding. However, in contrast to $\mathrm{Al}_{2} \mathrm{O}_{3}$, brazing of LTCC at $850^{\circ} \mathrm{C}$ was not tried as the LTCC is sintered at this temperature and the stability of the ceramic material is limited. In fact a repeated heating of the DuPont 951 tape up to the processing temperature is possible without any degradation of the microstructure. Scanning electron micrographs of the microstructures of Kovar- $\mathrm{Al}_{2} \mathrm{O}_{3}$ and Kovar-LTCC joints brazed with Cusil-ABA at $830^{\circ} \mathrm{C}$ are shown in Fig. 10a and $\mathrm{b}$, respectively. In these micrographs the brazing alloy displays the typically structure of the $\mathrm{Ag}-\mathrm{Cu}$ eutectic with a Ag-rich phase (white region) and a Cu-rich phase (grey regions). Furthermore, the formation of reaction layers on both interfaces is visible.

These reaction layers are shown in more detail in Fig. 11a and $b$. The active element titanium formed a continuous reaction layer with a thickness of $0.7-1 \mu \mathrm{m}$ bordering the interface between $\mathrm{Al}_{2} \mathrm{O}_{3}$ and the brazing alloy. The reaction layer consists of titanium and oxygen with minor amounts of $\mathrm{Ni}$, $\mathrm{Fe}$, and Co. The elemental composition is the same as observed for Kovar- $\mathrm{Al}_{2} \mathrm{O}_{3}$ joints brazed with Incusil-ABA. At the interface between Kovar and the brazing alloy an up to $3 \mu \mathrm{m}$ thick reaction layer with multiple phases was formed.
The main phase comprises a Fe-rich intermetallic compound ( $\mathrm{Fe}-\mathrm{Ni}-\mathrm{Co}-\mathrm{Ti})$ that covers the interface of the Kovar completely. Adjacent to the $\mathrm{Fe}-\mathrm{Ni}-\mathrm{Co}-\mathrm{Ti}$ phase a second $\mathrm{Ni}$ rich phase (Ni-Co-Fe-Ti) was found. A third intermetallic phase composed of $\mathrm{Ni}, \mathrm{Cu}$, and $\mathrm{Ti}$ is observed in the brazing alloy. The microstructural analysis of Kovar- $\mathrm{Al}_{2} \mathrm{O}_{3}$ joints brazed with Cusil-ABA and Incusil-ABA showed that during the active metal brazing processing similar phases were formed in the brazing seam. However, in the case of CusilABA the intermetallic compounds are located near the Kovar surface (Fig. 11b), whereas in the case of Incusil-ABA a lacework phase was formed (Fig. 6b). Additionally, while brazing with Cusil-ABA no penetration of the Kovar along the grain boundaries by the brazing alloy was observed (Fig. 10a and $b$ ). This leads to the conclusion that the reactivity of $\mathrm{Fe}$, $\mathrm{Ni}$, and $\mathrm{Co}$ with the active element titanium in the braze filler metals is enhanced because of the presence of indium or of the lower melting temperature of the $\mathrm{Ag}-\mathrm{Cu}-\mathrm{In}$ eutectic. The observation that the Incusil-ABA braze filler metal with the higher indium content leads to a stronger destruction of the Kovar microstructure along the grain boundaries lets one assume that especially the grain boundary phases of the Kovar consist of a alloy composition which forms low melting compositions with indium. A look at the binary phase diagrams iron-indium, cobalt-indium, and nickel-indium reveals that nickel and cobalt can form low melting phases under brazing conditions (Okamoto, 1997, 2003). In the case of iron this behaviour is shifted to higher temperatures and should not be pronounced below $800^{\circ} \mathrm{C}$ (Okamoto, 1990). On the other side according to Berry (1987) the grain boundary phases of Kovar-based alloys tend to form oxide-rich phases, which makes them susceptible to corrosion processes. So we should 

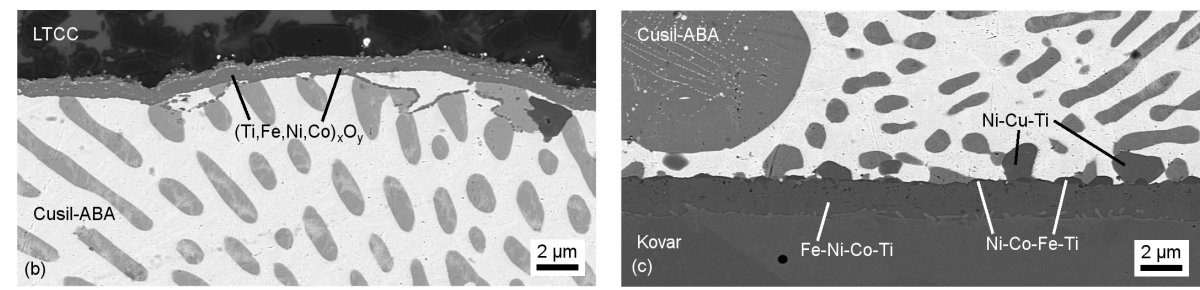

Figure 12. Enlarged SEM images of Fig. 10b showing the LTCC-Cusil-ABA (a) and the Kovar-Cusil-ABA interfaces (b).

Table 3. Compositions of interfacial reaction layers Cusil-ABALTCC at $830^{\circ} \mathrm{C}$ for $10 \mathrm{~min}$ and Incusil-ABA-LTCC after brazing at $755^{\circ} \mathrm{C}$ for $10 \mathrm{~min}$.

\begin{tabular}{lrr}
\hline $\begin{array}{l}\text { Element } \\
\text { Ma. } \%\end{array}$ & $\begin{array}{r}\text { Cusil-ABA- } \\
\text { LTCC }\end{array}$ & $\begin{array}{r}\text { Incusil-ABA- } \\
\text { LTCC }\end{array}$ \\
\hline $\mathrm{O}$ & 10.2 & 16.5 \\
$\mathrm{Al}$ & 0.6 & 1.6 \\
$\mathrm{Si}$ & 3.8 & 4.5 \\
$\mathrm{Ti}$ & 44.8 & 36.4 \\
$\mathrm{Fe}$ & 6.7 & 10.1 \\
$\mathrm{Co}$ & - & 3.9 \\
$\mathrm{Ni}$ & 8.2 & 10.1 \\
$\mathrm{Cu}$ & 25.8 & 13.0 \\
$\mathrm{In}$ & - & - \\
$\mathrm{Ag}$ & - & - \\
\hline
\end{tabular}

note that a more detailed investigation of the grain boundary phase is necessary in order to clarify this behaviour.

The microstructure of Kovar-LTCC joints brazed with Cusil-ABA is similar to the microstructure of Kovar- $\mathrm{Al}_{2} \mathrm{O}_{3}$ joints. Figure $12 \mathrm{a}$ and $\mathrm{b}$ are the enlarged images from Fig. 10b displaying the reaction layers at the interface between LTCC and the brazing alloy, and between Kovar and the brazing alloy, respectively. At the interface between LTCC and the brazing alloy a nearly $1 \mu \mathrm{m}$ thick reaction layer was formed (Fig. 12a). Besides the main constituents of titanium and oxygen, the EDX analysis revealed the presence of $\mathrm{Fe}, \mathrm{Ni}$, and $\mathrm{Co}$ from Kovar and of minor traces of silicon and lead from the glass phase of the LTCC. It is noteworthy that the compositions of the interfacial reaction layers bordering the LTCC interface are quite similar to the one found after brazing of LTCC and Kovar with Incusil-ABA as seen by EDX data in Table 3, which compares the compositions of the interfacial layers brazed with Cusil-ABA at $830^{\circ} \mathrm{C}$ and with Incusil-ABA at $755^{\circ} \mathrm{C}$. A large difference is only recognized for the copper content. However we should not forget the small thickness of the reaction layer in the case of Incusil-ABA which adds an uncertainty to the spectral data. So additionally in Table 4 similar results are presented for compositions of two interfacial layers resulting from brazing both LTCC and $\mathrm{Al}_{2} \mathrm{O}_{3}$ with Cusil-ABA at $850^{\circ} \mathrm{C}$ for $10 \mathrm{~min}$. However, the higher brazing temperature for CusilABA yielded a much thicker reaction layer than for samples
Table 4. Compositions of interfacial reaction layers Cusil-ABALTCC and Cusil-ABA- $\mathrm{Al}_{2} \mathrm{O}_{3}$ after brazing at $850^{\circ} \mathrm{C}$ for $10 \mathrm{~min}$.

\begin{tabular}{lrr}
\hline $\begin{array}{l}\text { Element } \\
\mathrm{Ma} . \%\end{array}$ & $\begin{array}{r}\text { Cusil-ABA- } \\
\text { LTCC }\end{array}$ & $\begin{array}{r}\text { Cusil-ABA- } \\
\mathrm{Al}_{2} \mathrm{O}_{3}\end{array}$ \\
\hline $\mathrm{O}$ & 14.3 & 12.5 \\
$\mathrm{Al}$ & 1.2 & 4.14 \\
$\mathrm{Si}$ & 4.7 & \\
$\mathrm{Ti}$ & 32.9 & 36.6 \\
$\mathrm{Fe}$ & 11.6 & 12.6 \\
$\mathrm{Co}$ & 5.6 & 4.7 \\
$\mathrm{Ni}$ & 24.0 & 25.0 \\
$\mathrm{Cu}$ & 4.5 & 4.3 \\
$\mathrm{Ag}$ & 1.0 & 1.3 \\
\hline
\end{tabular}

brazed with Incusil-ABA. The comparison of the interface between Kovar and the brazing alloy after brazing to $\mathrm{Al}_{2} \mathrm{O}_{3}$ (Fig. 11b) and LTCC (Fig. 12b) showed no difference in microstructural appearance like thickness, phases formed, or elemental composition. Based on these results it was decided to use the Cusil-ABA braze filler metal with a brazing temperature of $830^{\circ} \mathrm{C}$ for the construction of the complete sensor as shown in the next section.

\subsubsection{Joining of sensor and electrical connection}

In accordance with the integration procedure the last step involves the soldering of the sensor element by a glass paste which was screen-printed on the back side on the sensor and fired at maximum temperature of $550^{\circ} \mathrm{C}$. Joining and sealing processes for packaging of ceramic-based sensor elements are established for quite a long time, and so numerous qualified glass solders are available for this task. Figure 13a illustrates the final assembling steps of the sensor element into the steel connector with both brazed balancing elements made of Kovar and alumina. In Fig. 13b a SEM image shows the joining zones Kovar- $\mathrm{Al}_{2} \mathrm{O}_{3}$ and $\mathrm{Al}_{2} \mathrm{O}_{3}-\mathrm{LTCC}$ sensor of a completely assembled sensor. It can be seen that both zones contain only few pores and are well attached to each other. After the soldering step of the sensor a final measurement of the helium leakage rate was performed. Completely assembled sensors were mounted and characterized in the aforementioned pressure rail at temperatures up to $300^{\circ} \mathrm{C}$. As an example, Fig. 14 displays a set of characteristic curves of 

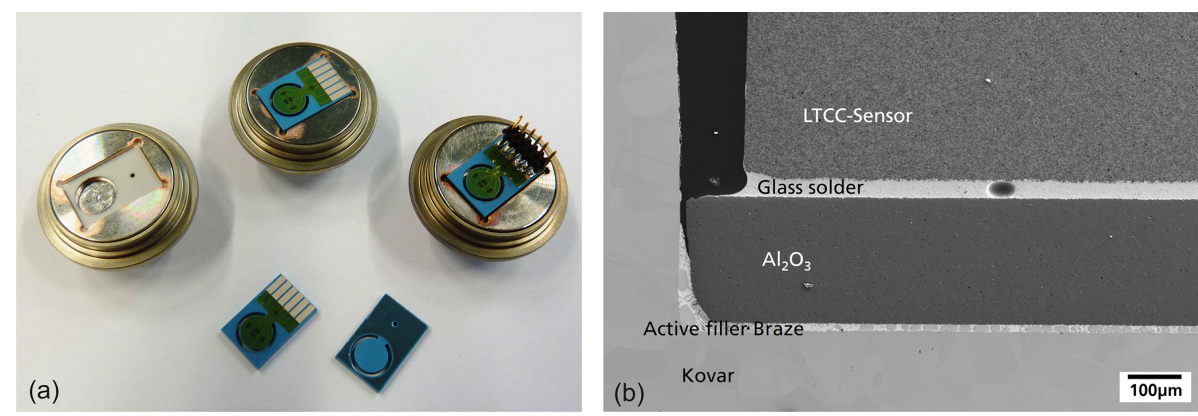

Figure 13. Joint components showing the stepwise integration procedure (a) and a SEM image of a cross section of a packaged LTCC pressure sensor (b).

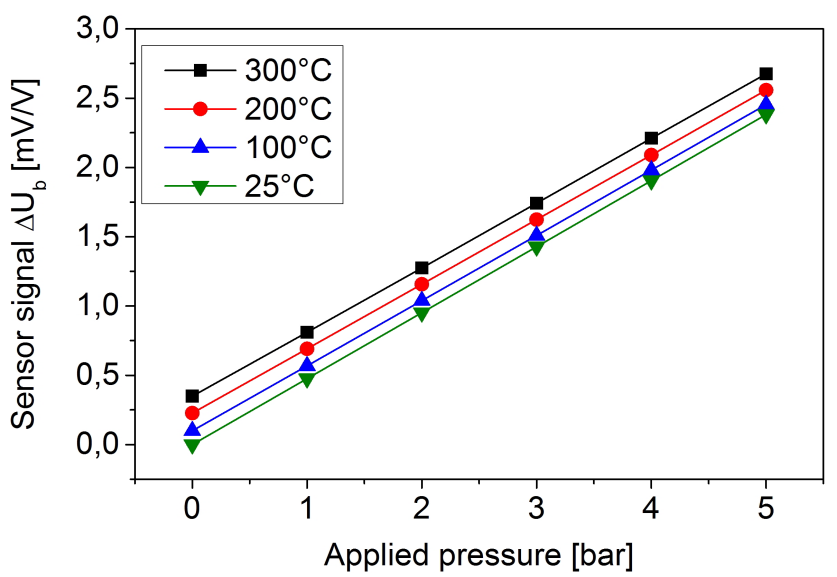

Figure 14. Temperature-dependent pressure-signal characteristics of a completely packaged LTCC sensor.

a completely assembled sensor based on an applied pressure (bar) and the corresponding sensor signal $(\Delta \mathrm{mV} / \mathrm{V})$ between 25 and $300^{\circ} \mathrm{C}$. The sensor signal shows a good linearity in the investigated pressure and temperature range. The sensitivity remains unaffected, and the particular curves are only shifted by a small offset, which can be compensated by an accompanied temperature measurement.

\section{Conclusions}

The present work focused on the joining process of Kovar with alumina and LTCC as part of on approach to integrate LTCC-based sensors into steel connects. While using commercially available active braze filler metals (CusilABA, Incusil-ABA, Incusil-25-ABA) under certain conditions, both ceramic types were hermetically sealed to Kovar. Hermetic joining of $\mathrm{Al}_{2} \mathrm{O}_{3}$ to Kovar was possible with Incusil-ABA and with Cusil-ABA for all investigated temperatures. Additionally, brazing of LTCC to Kovar was possible and shown for the first time. At $755^{\circ} \mathrm{C}$ with Incusil-ABA hermetic LTCC-Kovar joints were realized. The higher indium content of Incusil-25-ABA would enable lower brazing

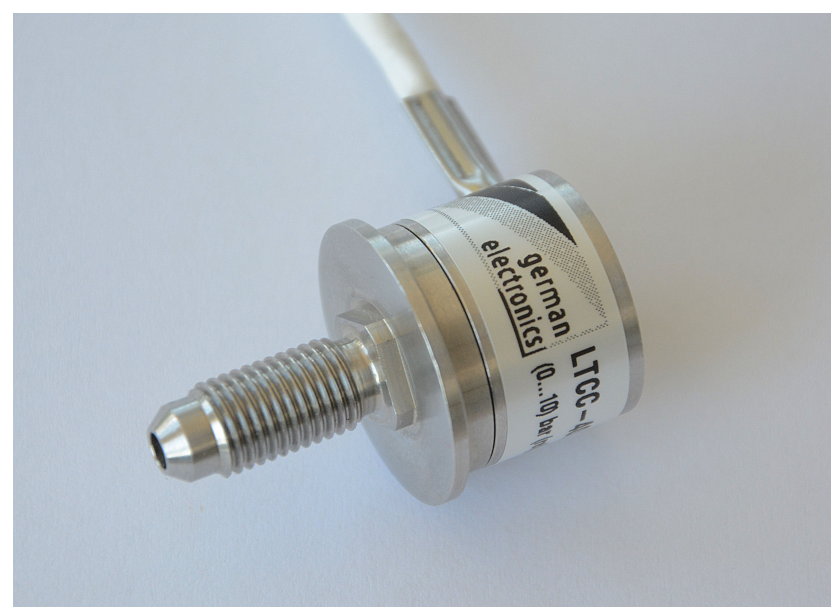

Figure 15. Completely assembled sensor with steel connect screw and welded steel housing with wiring.

temperatures, but the strong interaction with the Kovar metal and the porous brazing seams result in unreliable joints. With Cusil-ABA, joints were hermetically sealed at brazing temperatures $>810^{\circ} \mathrm{C}$. In all cases microstructural analysis revealed the development of intermetallic compounds that might be brittle, but their influence on the joint strength is unclear and will be investigated in the future. The combination of this metal-to-ceramic brazing step with additional joining processes allows the hermetic integration of a ceramic LTCC pressure sensor into steel housing with an adapted standardized thread (Fig. 15). 
Acknowledgements. The authors thank Felix Köhler, Birgit Manhica, Maria Striegler, and Sabine Fischer for sample preparation, helium leak rate measurement, and scanning electron microscopy.

Edited by: H. Fritze

Reviewed by: two anonymous referees

\section{References}

Arróyave, R. and Eagar, T. W.: Metal substrate effects on the thermochemistry of active brazing interfaces, Acta Mater., 51, 48714880, 2003.

Berry, K. A.: Corrosion Resistance of military microelectronics package at the lead-glass interface, in: Proceedings of the ASM's 3rd Conference on Electronic Packaging: Materials and Corrosion in Microelectronics, Minneapolis, MN, Materials Park, OH, ASM International, 28-30 April 1987, 55-61, 1987.

Fernie, J. A., Drew, R. A. L., and Knowles, K. M.: Joining of engineering ceramics, Int. Mater. Rev., 54, 283-331, 2009.

Fournier, Y., Maeder, T., Boutinard-Rouelle, G., Barras, A., Craquelin, N., and Ryse, P.: Integrated LTCC pressure flow temperature multisensor for compressed air diagnostics, Sensors, 10, 1115611173, 2010.

Hahn, S., Kim, M., and Kang, S.: A study of the reliability of brazed $\mathrm{Al}_{2} \mathrm{O}_{3}$ joint systems, IEEE Trans. Comp. Pack. Manuf. Tech. C., 21, 211-216, 1998.

Keusseyan, R. L. and Dilday, J. L.: Development of brazing interconnection to low thermal expansion glass-ceramics for high performance multichip packaging, Proc. of the 43rd Conference on Electronic Components and Technology, Orlando, FL, USA, 1-4 June 1993, 896-903, 1993.

Lin, K.-L., Singh, M., and Asthana, R.: Interfacial characterization of alumina-to-alumina joints fabricated using Silver-Coppertitanium interlayers, Mater. Char., 90, 40-51, 2014.

Liu, Y., Huang, Z. R., and Liu, X. J.: Joining of sintered silicon carbide using ternary $\mathrm{Ag}-\mathrm{Cu}-\mathrm{Ti}$ active brazing alloy, Cer. Int., 35, 3479-3484, 2009.

McDermid, J. R. and Drew, R. A. L.: Thermodynamic brazing alloy design for joining silicon carbide, J. Am. Cer. Soc., 74, 18551860, 1991.

Nascimento, R. M., Martinelli, A. E., and Buschinelli, A. J. A.: Review Article: Recent advances in metal-ceramic brazing, Cerâmica, 49, 178-198, 2003.

Nascimento, R. M., Martinelli, A. E., Buschinelli, A. J. A., and Sigismund, E.: Interface microstructure of alumina mechanically metallized with $\mathrm{Ti}$ brazed to $\mathrm{Fe}-\mathrm{Ni}$-Co using different fillers, Mater. Sci. Eng. A, 466, 195-200, 2007.

Okamoto, H.: Co-In (Cobalt-Indium), J. Phase Equilib., 18, p. 315, 1997.

Okamoto, H.: Fe-In (Iron-Indium), Binary Alloy Phase Diagrams, 2nd Edn., edited by: Massalski, T. B., 2, 1712-1714, 1990.
Okamoto, H.: In-Ni (Indium-Nickel), J. Phase Equilib., 24, p. 379 , 2003.

Partsch, U., Gebhardt, S., Arndt, D., Georgi, H., Neubert, H., Fleischer, D., and Gruchow, M.: LTCC based sensors for mechanical quantities, Proceedings of the 16th European Microelectronics and Packaging Conference \& Exhibition, Oulu, Finland, 17-20 June 2007, 381-388, 2007.

Partsch, U., Lenz, C., Ziesche, S., Lohrberg, C., Neubert, H., and Maeder, T.: LTCC-based sensors for mechanical quantities, Informacije MIDEM, 42, 260-271, 2012.

Peterson, K. A., Knudson, R. T., Garcia, E. J., Patel, K. D., Okandan, M., Ho, C. K., James, C. D., Rohde, S. B., Rohrer, B. R., Smith, F., Zawicki, L. R., and Wroblewski, B. D.: LTCC in microelectronics, microsystems, and sensors, Proceedings of the 15th International Conference on Mixed Design of Integrated Circuits and Systems, Poznan, Poland, 19-21 June 2008, 23-37, 2008.

Stephens, J. J., Vianco, P. T., Hlava, P. F., and Walker, C. A.: Microstructure and performance of Kovar/alumina joints made with Silver-Copper base active metal braze alloys, in: Advanced brazing and soldering technologies, edited by: Vianco, P. T. and Singh, M., ASM International (Materials Park), 240-251, 2000.

Stephens, J. J., Hosking, T. J., Headly, P. F., Hlava, P. F., and Yost, F. G.: Reaction layers and mechanisms for a Ti-activated braze on sapphire, Metall. Mater. Trans. A, 34, 2963-2972, 2003.

Vianco, P. T., Stephens, J. J., Hlava, P. F., and Walker C. A.: Titanium scavenging in Ag-Cu-Ti active braze joints, Weld. J., 82, 268S-277S, 2003a.

Vianco, P. T., Stephens, J. J., Hlava, P. F., and Walker C. A.: A barrier layer approach to limit $\mathrm{Ti}$ scavenging in $\mathrm{FeNiCo} / \mathrm{Ag}-\mathrm{Cu}-$ $\mathrm{Ti} / \mathrm{Al}_{2} \mathrm{O}_{3}$ active braze joints, Weld. J., 82, 252s-262s, 2003b.

Walker, C. A. and Hodges, V. C.: Comparing metal-ceramic brazing methods, Weld. J., 87, 43-50, 2008.

Walker, C. A. and Hodges, V. C.: Metal-nonmetal brazing for electrical, packaging and structural applications, in: Advances in Brazing: Science, Technology and Applications, edited by: Sekulić, D. P., Woodhead Publishing Oxford, 498-524, 2013.

Walker, C. A., Uribe, F., Monroe, S. L., Stephens, J. J., Goeke, R. S., and Hodges, V. C.: High-temperature joining of low-temperature co-fired ceramics, Proceedings of the 3th International Brazing and Soldering Conference, San Antonio, TX, USA, 24-26 April 2006, 54-59, 2006.

Wielage, B., Hoyer, I., and Hausner, S.: Induction brazing of alumina and zirconia with various metals, Proc. 5th International Brazing and Soldering Conference, Las Vegas, NV, USA, 22-25 April 2012, 101-108, 2012.

Zarnik, M. S., Mozek, M., Macek, S., and Belavic, D.: An LTCCbased capacitive pressure sensor with a digital output, Informacije MIDEM, 40, 74-81, 2010.

Zhu, W., Chen, J., Jiang, C., Hao, C., and Zhang, J.: Effects of Ti thickness on microstructure and mechanical properties of alumina-Kovar joints brazed with $\mathrm{Ag}-\mathrm{Pd} / \mathrm{Ti}$ filler, Ceram. Int., 40, 5699-5705, 2014. 